\title{
PROTOTIPE SISTEM PENDUKUNG KEPUTUSAN PEMILIHAN KARYAWAN TELADAN DENGAN MENGGUNAKAN METODE PROFILE MATCHING
}

\author{
Ruben Edward \\ Program Studi Informatika, Universitas Indraprasta PGRI \\ rubenerow@yahoo.com
}

\begin{abstract}
Abstrak
Tinggi rendahnya kinerja pekerja berkaitan erat dengan sistem pemberian penghargaan. Penghargaan dalam bentuk pemilihan karyawan teladan mendorong terciptanya karyawan yang mandiri, disiplin dan berprestasi. Pemilihan karyawan teladan yang tidak tepat dapat menimbulkan ketidak adilan dan berdampak pada motivasi kerja karyawan. Banyaknya karyawan, banyaknya kriteria dalam penilaian, potensi penilaian yang subjektif, dan sistem yang dilakukan masih bersifat manual membuat proses pemilihan karyawan teladan di PT SRI membutuhkan waktu yang lama. Untuk mengatasi permasalahan yang terjadi, maka dirancang sistem pendukung keputusan agar terciptanya sebuah keputusan yang lebih efektif dan efisien. Dengan adanya sistem yang baru diharapkan akan mempermudah dalam pencarian data, menghitung dalam penilaian pemilihan karyawan teladan, serta pengambilan keputusan. Dalam pembuatan sistem pendukung keputusan ini menggunakan metode Profile Matching dan melakukan studi kasus di PT SRI. aspek kriteria penelitian ini yaitu hasil kerja, kemampuan kerja, sikap kerja (attitude), kecerdasan, kepribadian dan partisipasi kerjasama. Sub kriteria kemudian dikategorikan dalam core factor dan secondary factor menggunakan metode GAP Analysis yang dikombinasikan dengan metode Profile Matching. Hasil dari penelitian berupa sebuah sistem pendukung keputusan yang membantu dalam pemilihan karyawan teladan secara objektif, cepat \& akurat.
\end{abstract}

Kata Kunci : Sistem Pendukung Keputusan, Profile Matching, Gap Analysis, Core Factor, Secondary Factor

\begin{abstract}
The high performance of workers is closely related to the reward system. The award in the form of selecting exemplary employees encourages the creation of self-employed, disciplined, and achieving employees. Improper employee role choices can lead to injustice and impact on employee motivation. Number of employees, the number of criteria in the assessment, the potential of subjective judgment, and the system is still a simple manual of work processes exemplary employees in PT SRI takes a long time. To solve the problems that occur, then prepare a decision support system for the creation of a more effective and efficient decision. With the new system is expected to enter in the search data, calculate in the assessment of selection of exemplary employees, and decision decision. In making this Decision Support System will use the method of Matching Case Study in PT SRI. This study discusses the analysis of the work, skills or skills, work attitude, knowledge (knowledge), Personality and socialization are categorized in the core and secondary factors using GAP methods Analysis in accordance with Profile Matching method. The result of the research is a decision support system capable of providing effective and efficient.
\end{abstract}

Keywords: Decision Support System, Profile Matching, GAP Analysis, Core Factor, Secondary Factor

\section{PENDAHULUAN}

Diberlakukannya SKKNI (Standar Kompetensi Kerja Nasional Indonesia) untuk sektor industri ban yang mengacu pada Peraturan Menteri Tenaga Kerja No.
124 Tahun 2016 mewajibkan setiap tenaga kerja harus memiliki standar kompetensi yang relevan dengan pelaksanaan tugas dan syarat jabatan tertentu. 
Tinggi rendahnya kinerja pekerja berkaitan erat dengan sistem pemberian penghargaan yang diterapkan oleh perusahaan tempat mereka bekerja. Pemberian penghargaan yang tidak tepat dapat berpengaruh terhadap peningkatan kinerja seseorang.

Penghargaan adalah bentuk pengakuan atau perhatian perusahaan terhadap prestasi yang ditunjukkan oleh karyawan. Hal ini dapat menimbulkan rasa percaya diri pada karyawan dan memotivasi untuk bekerja lebih baik. Penghargaan dapat berbentuk fisik dan nonfisik. Beberapa bentuk penghargaan yang diberikan oleh perusahaan terdiri dari penghargaan karyawan teladan, insentif penjualan dan promosi karyawan.

Pemilihan karyawan teladan sebaiknya dilakukan oleh pimpinan perusahaan. Hal ini bertujuan untuk menghemat waktu, mengurangi keterlibatan dalam semua hal, Adanya kesatuan pendapat dan mengurangi kesalahpahaman diantara pegawai tentang siapa yang mengerjakan dan siapa yang bertanggung jawab, Mengurangi frekuensi situasi dimana atasan tidak memiliki informasi pada saat dibutuhkan, dan agar pegawai mampu memperbaiki kesalahannya dan mengidentifikasikan sebab-sebab terjadinya kesalahan ataupun inefesiensi.

Pemilihan karyawan teladan di PT. SRI dilakukan oleh pimpinan perusahaan yang dibentuk dalam satu tim. Tim yang dibentuk terdiri dari beberapa anggota bertugas melakukan seleksi \& penilaian pada seluruh karyawan Golongan I - III. Banyaknya karyawan dan kriteria dalam penilaian, serta sistem yang dilakukan masih bersifat manual membuat proses pemilihan karyawan teladan membutuhkan waktu yang lama. Selain itu potensi penilaian yang subjektif dari tim penilai, menimbulkan ketidakadilan diantara karyawan dan berdampak pada motivasi kerja karyawan. masalah subjektifitas dan banyaknya kriteria dalam penilaian pemilihan karyawan teladan membuat pemilihan karyawan teladan tidak mudah dilakukan oleh pihak pimpinan ataupun tim yang ditunjuk. Permasalahan tersebut dapat diperbaiki dengan membangun sistem pendukung keputusan untuk pemilihan karyawan teladan dengan Menggunakan Metode Profile Matching.

\section{Prototipe}

Prototyping adalah proses interaktif dalam pengembangan sistem dimana kebutuhan (requirement) diubah kedalam sistem yang bekerja (working system) yang secara terusmenerus diperbaiki melalui kerjasama antara pengguna dengan pengembang. Berikut adalah proses yang dilakukan:

1. Mengetahui kebutuhan. Pada tahapan ini dilakukan komunikasi dan pertemuan ataupun Discussion Group untuk menentukan tujuan umum, kebutuhan yang diinginkan dan gambaran bagianbagian yang dibutuhkan berikutnya.

2. Perancangan. Pada tahapan ini dilakukan cepat dan rancangan mewakili aspek software yang diketahui serta menjadi dasar pembuatan prototipe.

3. Evaluasi. Pada tahapan ini dilakukan evaluasi yang telah dibuat oleh pengguna dan telah dipergunakan untuk memperjelas kebutuhan dari software.

\section{Sistem Pendukung Keputusan}

Sistem pendukung keputusan (SPK) merupakan sistem informasi komputer yang menghasilkan berbagai alternatif keputusan untuk membantu pemimpin dalam menangani berbagai permasalahan semi terstruktur dengan menggunakan data dan model. Sistem pendukung keputusan dibangun untuk mendukung solusi atas suatu masalah atau untuk mengevaluasi suatu peluang.

\section{Pemilihan Karyawan Teladan}

Penilaian karyawan teladan memiliki banyak kriteria/variabel. Kriteria tersebut juga disesuaikan dengan kebutuhan tiap perusahaan. Karyawan teladan diukur dari prestasi kerja, loyalitas dan prakarsa [5]. 
Kriteria lain adalah keahlian yang terdiri dari konsep, personal dan teknis; kepribadian yang terdiri dari jujur, tanggung jawab dan amanah; kerja tim yang memiliki sub kriteria kooperatif, kualitas kerja dan manajerial; penampilan yang mencakup sub kriteria menarik, kerapian dan keindahan dan sikap kerja yang mencakup kesopanan, keramahan dan tanggap.

\section{Metode Profile Matching}

Metode profile matching atau pencocokan profile adalah metode yang sering digunakan sebagai mekanisme dalam pengambilan keputusan dengan mengasumsikan bahwa terdapat tingkat variabel prediktor yang ideal yang harus dimiliki, bukan hanya tingkat minimal yang harus dipenuhi atau dilewati. Pada proses profile matching secara garis besar merupakan proses membandingkan antara nilai data actual dari suatu profil yang akan dinilai dengan nilai profil yang diharapkan, sehingga dapat diketahui perbedaan kompetensinya yang disebut sebagai gap, jika semakin kecil gap yang dihasilkan maka bobot nilainya semakin besar.

Dalam kasus pemilihan karyawan teladan dengan menggunakan metode profile matching (pencocokan profil) adalah membandingkan antara kompetensi profil karyawan teladan dengan nilai pencapaian hasil kinerja karyawan. Sehingga diketahui perbedaan kompetensinya (disebut gap). Jika hasil nilai gap semakin kecil maka bobot nilainya semakin besar dan berarti memiliki peluang lebih besar untuk menjadi karyawan teladan.

Dalam penentuan peringkat (ranking) Karyawan yang diperlukan untuk penilaian karyawan teladan yang

1. Sikap Kerja

2. Kecerdasan

3. Kepribadian

4. Partisipasi \& kerjasama

\section{METODE PENELITIAN}

\section{Metode Pemilihan Sampel}

Dalam penelitian ini, data dan informasi di kumpulkan dengan menggunakan teknik sampel dan pengamatan yang dilakukan pada karyawan PT Suryaraya Rubberindo Industri pada bagian Divisi engineering, Golongan I - III.

\section{Metode Pengumpulan Data}

Metode yang digunakan dalam pengumpulan data adalah :

1. Studi dokumentasi, dilakukan dengan mengambil data dari sumber yang sudah ada di bagian Divisi Engineering \& Human Resource Departement.

2. Studi literatur, dilakukan dengan cara melakukan pencarian jurnal, artikel, $e$ books, dan literatur yang membahas penilaian kinerja yang menggunakan berbagai metode yaitu, $A H P, S A W$, SMART, Profile Matching serta Fuzzy.

\section{Teknik Analisis Data}

Metode analisis dapat berdasarkan data yang diperoleh dari objek penelitian. Data akan diolah dengan menggunakan metode Metode Profile Matching dan PHP MySql. Output akhirnya akan menentukan nilai dari seorang karyawan teladan. Aplikasi yang dibuat akan dievaluasi untuk menghasilkan pengetahuan (knowledge) baru.

\section{Pembobotan}

Pada tahap ini akan ditentukan bobot nilai masing masing aspek dengan menggunakan bobot nilai yang telah ditentukan bagi masing-masing aspek itu sendiri. Dalam penentuan peringkat pada aspek kapasitas intelektual, sikap kerja, dan perilaku untuk jabatan yang sama pada setiap gap, diberikan bobot nilai sesuai dengan tabel berikut : 
Tabel 1. Keterangan Bobot Nilai Gap

\begin{tabular}{|c|c|c|c|}
\hline No & $\begin{array}{c}\text { Selisih } \\
\text { Gap }\end{array}$ & $\begin{array}{l}\text { Bobot } \\
\text { Nilai }\end{array}$ & Keterangan \\
\hline 1 & 0 & 5 & $\begin{array}{l}\text { Kompetensi } \\
\text { sesuai dengan } \\
\text { yang } \\
\text { dibutuhkan }\end{array}$ \\
\hline 2 & 1 & 4,5 & $\begin{array}{l}\text { Kompetensi } \\
\text { individu } \\
\text { kelebihan } 1 \\
\text { tingkat/level }\end{array}$ \\
\hline 3 & -1 & 4 & $\begin{array}{l}\text { Kompetensi } \\
\text { individu } \\
\text { kurang } 1 \\
\text { tingkat/level }\end{array}$ \\
\hline 4 & 2 & 3,5 & $\begin{array}{l}\text { Kompetensi } \\
\text { individu } \\
\text { kelebihan } 2 \\
\text { tingkat/level }\end{array}$ \\
\hline 5 & -2 & 3 & $\begin{array}{l}\text { Kompetensi } \\
\text { individu } \\
\text { kurang } 2 \\
\text { tingkat/level }\end{array}$ \\
\hline 6 & 3 & 2,5 & $\begin{array}{l}\text { Kompetensi } \\
\text { individu } \\
\text { kelebihan } 3 \\
\text { tingkat/level }\end{array}$ \\
\hline 7 & -3 & 2 & $\begin{array}{l}\text { Kompetensi } \\
\text { individu } \\
\text { kurang } 3 \\
\text { tingkat/level }\end{array}$ \\
\hline 8 & 4 & 1,5 & $\begin{array}{l}\text { Kompetensi } \\
\text { individu } \\
\text { kelebihan } 4 \\
\text { tingkat/level }\end{array}$ \\
\hline 9 & -4 & 1 & $\begin{array}{l}\text { Kompetensi individu } \\
\text { kurang } 4 \\
\text { tingkat/level }\end{array}$ \\
\hline
\end{tabular}

Sumber : [9]

\section{Pengelompokan Core factor dan} Secondary Factor

Setelah menentukan bobot nilai gap kriteria yang dibutuhkan, kemudian tiap kriteria dikelompokkan lagi menjadi dua kelompok yaitu core factor dan secondary factor.

a. Core factor (Faktor Utama)

Core factor merupakan aspek (kompetensi) yang menonjol atau paling dibutuhkan oleh suatu jabatan yang diperkirakan dapat menghasilkan kinerja optimal.

Untuk menghitung core factor digunakan rumus [9]:

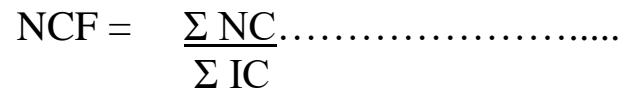

Keterangan :

NCF : Nilai rata - rata core factor

NC : Jumlah total nilai core factor

IC : Jumlah item core factor

b. Secondary Factor (faktorpendukung) Secondary factor adalah item - item selain aspek yang ada pada core factor. Untuk menghitung secondary factor digunakan rumus [9] :

$$
\mathrm{NSF}=\frac{\sum \mathrm{NS}}{\Sigma \mathrm{IS}}
$$

Keterangan :

NSF : Nilai rata - rata secondary factor NS : Jumlah total nlai secondary factor IS : Jumlah item secondary factor

Rumus diatas adalah rumus untuk menghitung core factor dan secondary factor dari aspek - aspek sub kriteria yang ada.

1. Perhitungan Nilai Total

Dari perhitungan core factor dan secondary factor dari tiap tiap aspek, kemudian dihitung nilai total dari tiap tiap aspek yang diperkirakan berpengaruh pada kinerja tiap tiap profil.

Untuk menghitung nilai total dari masing masing aspek, digunakan rumus [9] :

$\begin{array}{cl}\mathrm{Ni}=(\mathrm{X}) \% \mathrm{NCF} & +(\mathrm{X}) \% \text { NS........... (3) } \\ \text { Keterangan } & \text { : } \\ \mathrm{Ni} & \text { Nilai total tia paspek } \\ \mathrm{NCF} & \text { : Nilai rata-rata core } \\ & \text { factor } \\ \mathrm{NSF} & \text { : Nilai rata rata } \\ & \text { secondary factor } \\ (\mathrm{X}) \% & \text { : Nilai presentase } \\ & \text { yang di inputkan }\end{array}$


2. Perankingan

Hasil akhir dari proses profile matching adalah rangking dari kandidat yang diajukan untuk mengisi suatu jabatan/posisi tertentu. Penentuan mengacu ranking pada hasil perhitungan yang ditunjukkan oleh rumus [9] :

Rangking $=60 \% \mathrm{NCF}+40 \% \mathrm{NSF}$.

Keterangan :

NCF : Nilai core factor

NSF : Nilai secondary factor

Dari perhitungan tersebut akan dilakukan pengujian dengan Black Box yaitu pengujian yang dilakukan hanya mengamati hasil eksekusi melalui data uji dan memeriksa fungsional dari perangkat lunak dan Focus Group Discussion (FGD) yaitu suatu diskusi yang dilakukan secara sistematis dan terarah mengenai suatu isu atau masalah tertentu.

\section{HASIL DAN PEMBAHASAN}

\section{Diagram Use Case}

Diagram Use Case adalah sebuah diagram yang digunakan untuk menunjukan tampilan grafis dari fungsionalitas yang diberikan oleh sistem dilihat dari sisi aktor, tujuan aktor, dan hal yang berkaitan dengan use case yang ada.

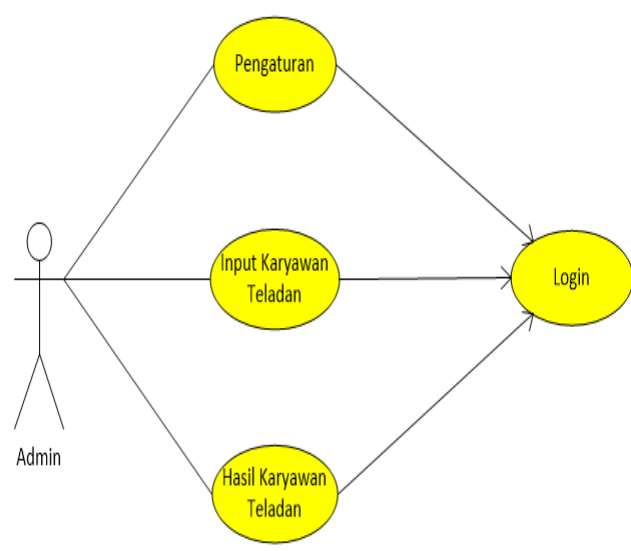

Gambar 1. Use Case Diagram untuk Pemilihan Karyawan Teladan
Use Case Login

Use Case : Login

Aktor : Admin

Tujuan : Melakukan

Autentifikasi User

Deskripsi : Use case login dengan memasukan username dan pasword yang kemudian sistem akan melakukan validasi.

\section{Sequence Diagram}

Berikut sequence diagram untuk sistem pengambilan keputusan penentuan karyawan teladan :

Sequence diagram untuk Use Case login

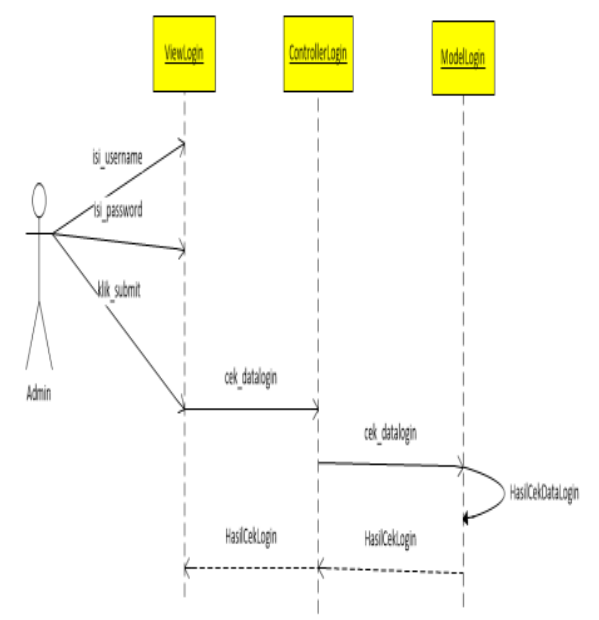

Gambar 2. Sequence Diagram Login

\section{Activity Diagram}

Activity Diagram login

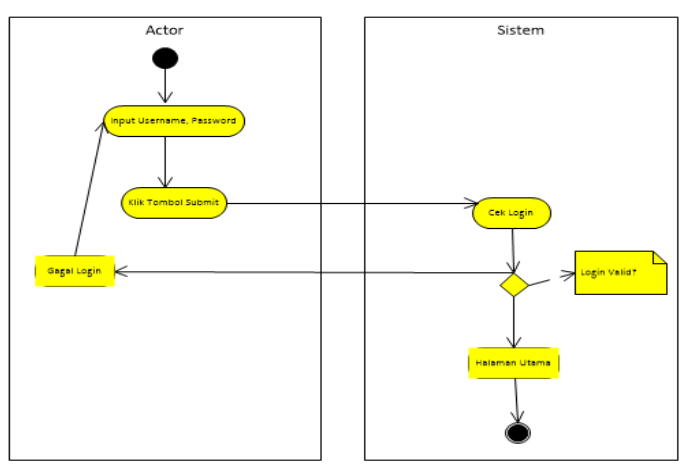

Gambar 3. Activity Diagram Login 


\section{Perancangan Layar}

1. Halaman Login

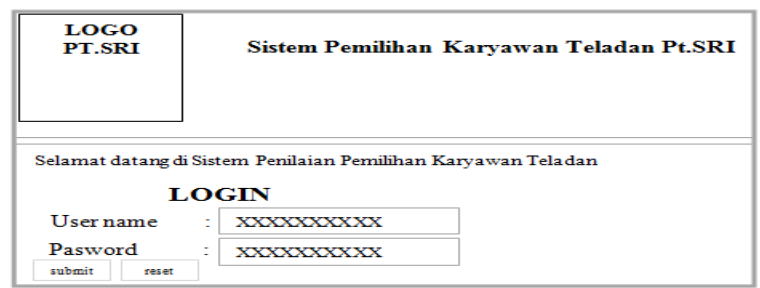

Gambar 4. Perancangan Halaman Login

Admin input username dan password kemudian klik tombol submit untuk bisa ke halaman penilaian kinerja pegawai.

2. Halaman Administrator Sistem Pemilihan Karyawan teladan

\begin{tabular}{|c|c|c|c|}
\hline $\begin{array}{c}\text { LOGO } \\
\text { PT.SRI }\end{array}$ & \multicolumn{3}{|c|}{ Sistem Pemilihan Karyawan Teladan Pt.SRI } \\
\hline \hline HOME & PENGATURAN & $\begin{array}{c}\text { KARYAWAN } \\
\text { TELADAN }\end{array}$ & LOG OUT \\
\hline
\end{tabular}

Gambar 5. Perancangan Halaman Administrator

3. Halaman Hasil

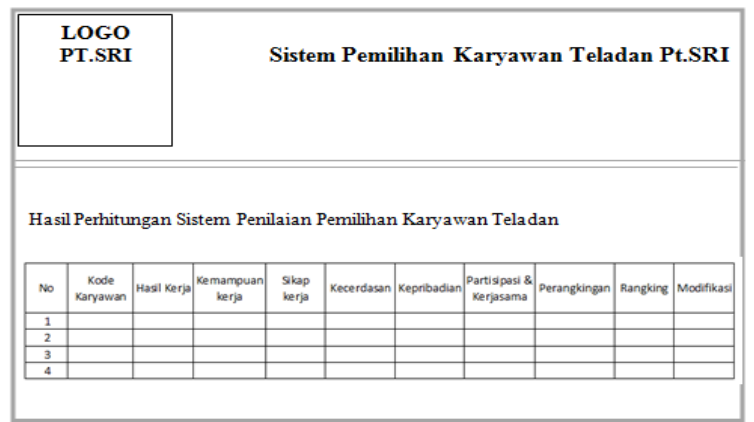

Gambar 6. Perancangan Halaman Hasil

\section{Tampilan Sistem Yang Dirancang}

1. Tampilan Login

Sistem Pemilihan Karyawan Teladan PT SRI
Manufacturer of Motorcycle Tires \& Tubes
Selamat datang di Sistem Penilaian Pemilihan Karyawan Teladan
LOGIN
\begin{tabular}{ll} 
Username & isikan akun anda \\
Password & \\
\hline submit reset
\end{tabular}

\section{Gambar 7. Form Login}

Ketika program pertama kali akan di run, maka akan tampil form login dengan gambar seperti di atas. Pada halaman ini admin harus mengisi username dan password agar dapat masuk ke halaman selanjutnya.

2. Tampilan Administrator Sistem Pemilihan Karyawan Teladan

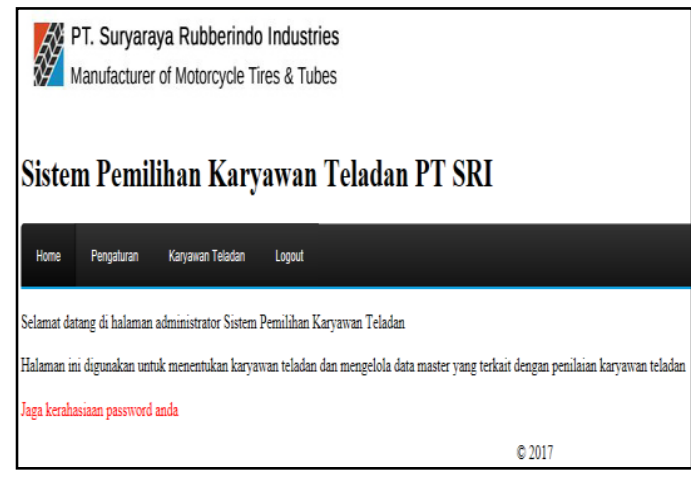

Gambar 8. Halaman Adminstrator

3. Tampilan Input Pemilihan Karyawan Teladan

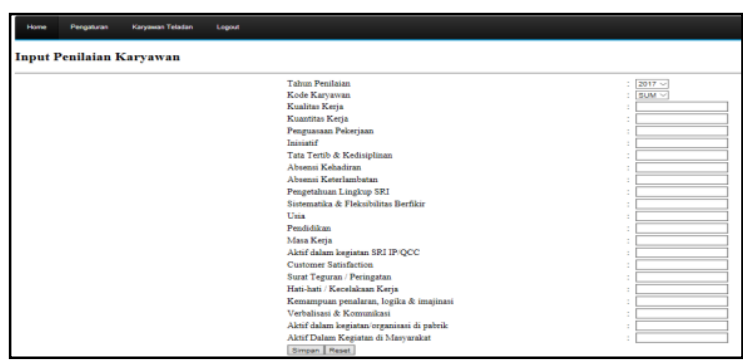

\section{Gambar 9. Halaman Input Pemilihan Karyawan Teladan}

Apabila login berhasil maka akan tampil form penilaian seperti gambar diatas. Pada Form menu Penilaian admin dapat

Ruben Edward, Prototipe Sistem Pendukung ... 
menginput Data Pegawai dan Nilai Profile Karyawan.Tujuannya untuk menginput data nilai masing-masing karyawan ke dalam database.

\section{Tampilan Form Hasil}

Pada Form menu Hasil menampilkan nilai akhir dari hasil penilaian kinerja Karyawan yang telah diproses berdasarkan kriteria dan bobot menggunakan metode Profile Matching, karyawan yang memiliki nilai kinerja yang ideal berpeluang untuk di jadikan sebagai karyawan teladan.

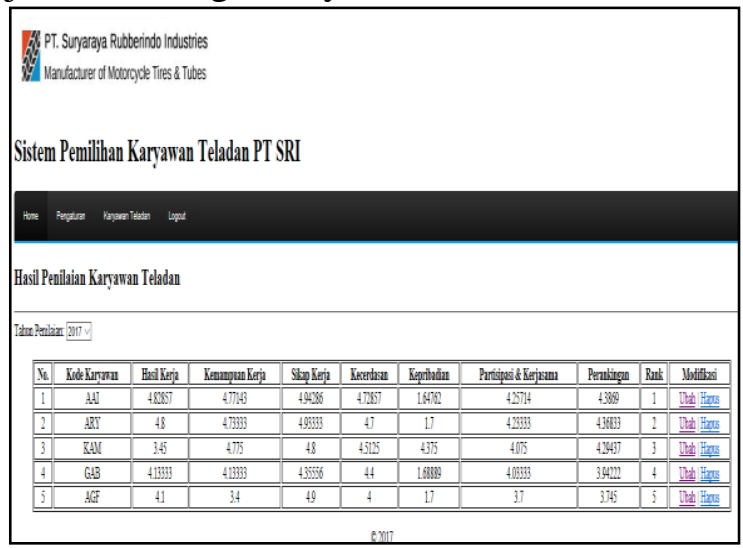

Gambar 10. Form Menu Hasil

\section{Perhitungan Metode Profile Matching}

Dalam pemilihan karyawan teladan menggunakan metode profile matching, diperlukan kriteria-kriteria, kategori dan bobot untuk melakukan perhitungan. Dalam kasus ini dibagi menjadi enam Aspek kriteria, yaitu hasil kerja, kemampuan kerja, sikap kerja, kecerdasan, kepribadian, partisipasi \& kerjasama. Setiap Aspek kriteria memiliki Subkriteria. Untuk kategori ada dua sub yaitu, core factor \& secondary factor. Untuk core factor memiliki bobot $60 \%$, sedangkan secondary factor memiliki bobot $40 \%$. core factor \& secondary factor di tentukan berdasarkan sub kriteria yang paling diprioritaskan. Keluaran yang nantinya dihasilkan adalah urutan alternatif yang tertinggi sampai terendah. Ada 20 sub kriteria yang digunakan untuk melakukan penilaian, yaitu:
1. Kualitas kerja

2. Kuantitas kerja

3. Penguasaan pekerjaan

4. Inisiatif

5. Tata tertib \& kedisiplinan

6. Absensi kehadiran

7. Absensi keterlambatan

8. Surat teguran \& peringatan

9. Kecelakaan kerja

10. Pengetahuan Lingkup SRI

11. Sistematika \& Fleksibitas berfikir

12. Kemampuan penalaran,logika \& imajinasi

13. Verbalisasi \& Komunikasi

14. Usia

15. Pendidikan

16. Masa kerja

17. Aktif dalam kegiatan Ide Proposal \& QCC

18. Customer satisfaction

19. Aktif dalam kegiatan / organisasi pabrik

20. Aktif dalam kegiatan masyarakat

Tabel 2. Bobot Aspek Kriteria

\begin{tabular}{|c|l|c|}
\hline No & \multicolumn{1}{|c|}{ Kriteria } & Bobot (\%) \\
\hline 1 & Hasil Kerja & 20 \\
\hline 2 & Kemampuan Kerja & 20 \\
\hline 3 & Sikap Kerja & 15 \\
\hline 4 & Kecerdasan & 15 \\
\hline 5 & Kepribadian & 10 \\
\hline 6 & Partisipasi \& kerjasama & 20 \\
\hline \multicolumn{2}{|c|}{ Sumber : Pembobotan PT.SRI } \\
\hline
\end{tabular}

Setelah kriteria dan bobot telah ditentukan pada tabel diatas, dilanjutkan dengan penentuan nilai pada setiap karyawan yang akan dilakukan penilaian. Ada 7 orang karyawan yang menjadi kandidat (alternatif) untuk dilakukan penilaian dalam memilih karyawan teladan, yaitu :

1. Karyawan JAR

2. Karyawan ARY

3. Karyawan KAM

4. Karyawan GAB

5. Karyawan AGF

6. Karyawan SGD

7. Karyawan SUM 


\section{Langkah-langkah pada Metode Profile Matching}

Langkah-langkah pada metode profile matching yaitu :

1. Menentukan variabel-variabel pemetaan Gap kompetensi, menentukan aspekaspek yang akan digunakan dalam memproses nilai karyawan.

2. Menghitung hasil pemetaan Gap kompetensi. Yang dimaksud dengan Gap disini adalah beda antara profil karyawan dengan profil karyawan teladan yang diharapkan. atau dapat ditunjukkan pada rumus di bawah ini:

Gap = Profil pegawai - Profil karyawan teladan......(5)

Untuk mengetahui nilai Sub kriteria yang akan digunakan, maka kita akan tentukan sebagai berikut:

1. Untuk Sub kriteria yang termasuk Core Factor

a. Kualitas Kerja :

$$
\begin{aligned}
0-60 & =1 \\
61-70 & =2 \\
71-80 & =3 \\
81-90 & =4 \\
91-100 & =5
\end{aligned}
$$

b. Penguasaan Pekerjaan :

$$
\begin{aligned}
0-60 & =1 \\
61-70 & =2 \\
71-80 & =3 \\
81-90 & =4 \\
91-100 & =5
\end{aligned}
$$

c. Tata tertib \& Kedisiplinan :

$$
\begin{aligned}
0-60 & =1 \\
61-70 & =2 \\
71-80 & =3 \\
81-90 & =4 \\
91-100 & =5
\end{aligned}
$$

d. Absensi Kehadiran :

$$
\begin{array}{cc}
5-10 & =1 \\
3-4 & =2 \\
2 & =3 \\
1 & =4 \\
0 & =5
\end{array}
$$

e. Kecelakan Kerja :

$$
\begin{array}{ll}
2-3 & =0 \\
0 & =5
\end{array}
$$

f. Pengetahuan Lingkup SRI :

$$
\begin{aligned}
0-60 & =1 \\
61-70 & =2 \\
71-80 & =3 \\
81-90 & =4 \\
91-100 & =5
\end{aligned}
$$

g. Verbalisai \& Komunikasi :

$$
\begin{aligned}
0-60 & =1 \\
61-70 & =2 \\
71-80 & =3 \\
81-90 & =4 \\
91-100 & =5
\end{aligned}
$$

h. Masa Kerja :

$$
\begin{aligned}
0-1 \text { tahun } & =1 \\
2-4 \text { tahun } & =2 \\
5-7 \text { tahun } & =3 \\
8-10 \text { tahun } & =4 \\
11-30 \text { tahun } & =5
\end{aligned}
$$

i. Aktif dalam kegiatan IP \& QCC :

$$
\begin{array}{ll}
0-60 & =1 \\
61-70 & =2 \\
71-80 & =3 \\
81-90 & =4 \\
91-100 & =5
\end{array}
$$

j. Aktif dalam kehidupan masyarakat

$$
\begin{array}{cl}
0-60 & =1 \\
61-70 & =2 \\
71-80 & =3 \\
81-90 & =4 \\
91-100 & =5
\end{array}
$$

2. Untuk Kriteria yang termasuk Secondary Factor

a. Kualitas Kerja :

$$
\begin{aligned}
0-60 & =1 \\
61-70 & =2 \\
71-80 & =3 \\
81-90 & =4 \\
91-100 & =5
\end{aligned}
$$


b. Inisiatif :

$$
\begin{aligned}
0-60 & =1 \\
61-70 & =2 \\
71-80 & =3 \\
81-90 & =4 \\
91-100 & =5
\end{aligned}
$$

c. Absensi Kehadiran :

$$
\begin{array}{cl}
5-10 & =1 \\
3-4 & =2 \\
2 & =3 \\
1 & =4 \\
0 & =5
\end{array}
$$

d. Surat Teguran \& Peringatan :

$$
\begin{gathered}
2-3=0 \\
0=5
\end{gathered}
$$

e. Sistematika \& Fleksibilitas Berfikir :

$$
\begin{aligned}
0-60 & =1 \\
61-70 & =2 \\
71-80 & =3 \\
81-90 & =4 \\
91-100 & =5
\end{aligned}
$$

f. Kemampuan imajinasi \&

\begin{tabular}{|c|c|c|c|c|}
\hline No & $\begin{array}{c}\text { Aspek } \\
\text { Kriteria }\end{array}$ & Nama Kriteria & $\begin{array}{c}\text { Nilai Profil } \\
\text { Karyawan } \\
\text { Teladan }\end{array}$ & Keterangan \\
\hline \multirow[b]{2}{*}{1} & \multirow{2}{*}{ Hasil Kerja } & Kualitas kerja & 4 & $81-90$ \\
\hline & & $\begin{array}{l}\text { Kuantitas } \\
\text { kerja }\end{array}$ & 4 & $81-90$ \\
\hline \multirow{2}{*}{2} & \multirow{2}{*}{$\begin{array}{l}\text { Kemampuan } \\
\text { Kerja }\end{array}$} & $\begin{array}{l}\text { Penguasaan } \\
\text { Pekerjaan }\end{array}$ & 4 & $81-90$ \\
\hline & & Inisiatif & 4 & $81-90$ \\
\hline \multirow{5}{*}{3} & \multirow{5}{*}{ Sikap Kerja } & $\begin{array}{l}\text { Tata tertib \& } \\
\text { kedisipilnan }\end{array}$ & 4 & $81-90$ \\
\hline & & $\begin{array}{l}\text { Absensi } \\
\text { kehadiran }\end{array}$ & 5 & 0 \\
\hline & & $\begin{array}{l}\text { Absensi } \\
\text { keterlambatan }\end{array}$ & 5 & 0 \\
\hline & & $\begin{array}{l}\text { Surat Teguran } \\
\& \text { Peringatan }\end{array}$ & 5 & 0 \\
\hline & & $\begin{array}{l}\text { Kecelakaan } \\
\text { kerja }\end{array}$ & 5 & 0 \\
\hline \multirow{4}{*}{4} & \multirow{4}{*}{ Kecerdasan } & $\begin{array}{l}\text { Pengetahuan } \\
\text { Lingkup SRI }\end{array}$ & 4 & $81-90$ \\
\hline & & $\begin{array}{l}\text { Sistematika \& } \\
\text { Fleksibilitas } \\
\text { berfikir }\end{array}$ & 3 & $71-80$ \\
\hline & & $\begin{array}{l}\text { Kemampuan } \\
\text { penalaran,logi } \\
\text { ka \& imajinasi }\end{array}$ & 4 & $81-90$ \\
\hline & & $\begin{array}{l}\text { Verbalisasi \& } \\
\text { komunikasi }\end{array}$ & 4 & $81-90$ \\
\hline \multirow{3}{*}{5} & \multirow{3}{*}{ Kepribadian } & Usia & 3 & $32-36$ \\
\hline & & Pendidikan & 2 & SMU \\
\hline & & Masa kerja & 4 & 3 Tahun \\
\hline
\end{tabular}
Penalaran Logika:

$$
\begin{aligned}
0-60 & =1 \\
61-70 & =2 \\
71-80 & =3 \\
81-90 & =4 \\
91-100 & =5
\end{aligned}
$$

g. Usia :

$$
\begin{aligned}
& 19-30=1 \\
& 31-35=2 \\
& 36-41=3 \\
& 42-48=4 \\
& 50-55=5
\end{aligned}
$$

h. Pendidikan :

$\begin{array}{ll}\text { SMP } & =1 \\ \text { SMU } & =2 \\ \text { D3 } & =3 \\ \text { S1 } & =4 \\ \text { S2 } & =5\end{array}$

i. Customer satisfaction:

$$
\begin{aligned}
0-60 & =1 \\
61-70 & =2 \\
71-80 & =3 \\
81-90 & =4 \\
91-100 & =5
\end{aligned}
$$

j. Aktif dalam kehidupan masyarakat

$$
\begin{aligned}
0-60 & =1 \\
61-70 & =2 \\
71-80 & =3 \\
81-90 & =4 \\
91-100 & =5
\end{aligned}
$$

\subsection{Penentuan Nilai Profile Karyawan Teladan}

Tabel 3. Nilai yang harus dicapai oleh setiap karyawan, yang akan di pilih menjadi karyawan teladan 


\begin{tabular}{|c|c|l|c|c|}
\hline \multirow{2}{*}{ No } & $\begin{array}{c}\text { Aspek } \\
\text { Kriteria }\end{array}$ & Nama Kriteria & $\begin{array}{c}\text { Nilai Profil } \\
\text { Karyawan } \\
\text { Teladan }\end{array}$ & Keterangan \\
\hline \multirow{2}{*}{6} & \multirow{2}{*}{$\begin{array}{l}\text { Partisipasi \& } \\
\text { kerjasama }\end{array}$} & $\begin{array}{l}\text { Aktif dalam } \\
\text { kegiatan IP \& } \\
\text { QCC }\end{array}$ & 5 & $91-100$ \\
\cline { 3 - 5 } & $\begin{array}{l}\text { Customer } \\
\text { satisfaction }\end{array}$ & 4 & $81-90$ \\
\cline { 3 - 5 } & $\begin{array}{l}\text { Aktif dalan } \\
\text { kegiatan } \\
\text { /organisasi di } \\
\text { pabrik }\end{array}$ & 4 & $81-90$ \\
\cline { 3 - 5 } & $\begin{array}{l}\text { Aktif dalan } \\
\text { kegiatan di } \\
\text { masyarakat }\end{array}$ & 5 & $91-100$ \\
\hline
\end{tabular}

\section{Penghitungan GAP}

Yang dimaksud dengan Gap disini adalah beda antara profil pegawai dengan profil karyawan teladan yang diharapkan. atau dapat ditunjukkan pada rumus di bawah ini: Gap=Profil pegawai - Profil karyawan teladan

\section{Pembobotan}

Setelah diperoleh GAP untuk masingmasing Kriteria disetiap karyawan, selanjutnya setiap kriteria profil karyawan kita beri bobot nilai sesuai dengan ketentuan pada Tabel Bobot Nilai

Tabel 4. Menentukan nilai bobot dari nilai yang dihasilkan oleh rumus

\begin{tabular}{|c|c|c|}
\hline Selisih & $\begin{array}{l}\text { Bobot } \\
\text { Nilai }\end{array}$ & Keterangan \\
\hline 0 & 5 & $\begin{array}{l}\text { Tidak ada selisih (Kompetensi } \\
\text { sesuai dengan yang dibutuhkan) }\end{array}$ \\
\hline 1 & 4.5 & $\begin{array}{l}\text { Kompetensi individu kelebihan } \\
1 \text { tingkat }\end{array}$ \\
\hline-1 & 4 & $\begin{array}{l}\text { Kompetensi individu } \\
\text { kekurangan } 1 \text { tingkat }\end{array}$ \\
\hline 2 & 3.5 & $\begin{array}{l}\text { Kompetensi individu kelebihan } \\
2 \text { tingkat }\end{array}$ \\
\hline-2 & 3 & $\begin{array}{l}\text { Kompetensi individu } \\
\text { kekurangan } 2 \text { tingkat }\end{array}$ \\
\hline 3 & 2.5 & $\begin{array}{l}\text { Kompetensi individu kelebihan } \\
3 \text { tingkat }\end{array}$ \\
\hline-3 & 2 & $\begin{array}{l}\text { Kompetensi individu } \\
\text { kekurangan } 3 \text { tingkat }\end{array}$ \\
\hline 4 & 1.5 & $\begin{array}{l}\text { Kompetensi individu kelebihan } \\
4 \text { tingkat }\end{array}$ \\
\hline-4 & 1 & $\begin{array}{l}\text { Kompetensi individu } \\
\text { kekurangan } 4 \text { tingkat }\end{array}$ \\
\hline
\end{tabular}

Perhitungan Core dan Secondary Factor Kemudian setiap kriteria dikelompokan menjadi 2 kelompok, yaitu kelompok Core Factor dan Secondary Factor. Perhitungan core factor ditunjukkan menggunakan rumus dibawah ini:

$$
\begin{aligned}
\mathrm{NCF} & =\frac{\sum \mathrm{NC}}{\sum \mathrm{IC}} \\
\mathrm{NSF} & =\frac{\sum \mathrm{NS}}{\sum \mathrm{IS}} . . .
\end{aligned}
$$

\section{Perhitungan Nilai Total}

Dari hasil perhitungan setiap aspek, berikutnya dihitung nilai total berdasarkan presentase dari core dan secondary yang diperkirakan berpengaruh.

$\mathrm{Ni}=60 \% \quad(\mathrm{NCF})+40$ $\%$ (NSF)

\section{Perhitungan Nilai Ranking}

Hasil akhir dari proses Profile Matching adalah ranking dari kandidat yang akan di ajukan untuk mennjadi karyawan teladan. Penentuan ranking mengacu pada hasil perhitungan yang di ajukan pada rumus berikut [9]:

Ranking $=(\mathrm{x}) \% \mathrm{~N} 1+(\mathrm{x}) \% \mathrm{Nn}$

Keterangan :

$\mathrm{N}=$ Nilai Total Tiap Aspek

(x) $\%=$ Nilai Persentase Kriteria

Contoh perhitungan ranking karyawan Jaf : Ranking $=(20 \%$ Aspek Kerja $)+(20 \%$ Kemampuan Kerja $)+(15 \%$ Sikap Kerja $)+$ $(15 \%$ Kecerdasan $)+(10 \%$ Kepribadian $)+$ (20\% Pertisipasi \& Kerjasama

Ranking $=(20 \% \times 4,0)+(20 \% \times 4,6)+$ $(15 \% \times 4,8)+(15 \% \times 3,5)+(10 \% \times 4,4)+$ $(205 \times 2,8)=3,97$

\section{Pelaporan}

Berdasarkan hasil perhitungan yang telah dilaksanakan oleh penulis terhadap Prototipe Sistem Pendukung Keputusan untuk pemilihan karyawan teladan dengan metode Profile matching maka peringkat yang dihasilkan adalah sebagai berikut:
1. Karyawan KAM dengan Nilai Akhir 4.61

Ruben Edward, Prototipe Sistem Pendukung ... 
2. Karyawan AGF dengan Nilai Akhir 4.49

3. Karyawan Akhir 4.27

4. Karyawan GAB dengan Nilai Akhir 4.04

5. Karyawan SUG dengan Nilai Akhir 4.01

6. Karyawan JAF dengan Nilai Akhir 3.97

7. Karyawan SUM dengan Nilai Akhir 3.58

\section{SIMPULAN}

Dari penelitian dan pembahasan yang telah dilakukan, beberapa kesimpulan yang bisa diambil diantaranya :

1. Sistem pendukung keputusan dengan menggunakan metode Profile Matching dapat digunakan dalam pemilihan karyawan teladan Divisi Engineering dan divisi-divisi lain yang ada di PT. SRI.

2. Sistem pendukung keputusan pemilihan karyawan teladan dengan menggunakan metode profile matching dapat membantu pimpinan dalam pemilihan karyawan teladan secara objektif, cepat \& akurat.

\section{DAFTAR PUSTAKA}

[1] A.A. Anwar Prabu Magkunegara. Manajemen Sumber Daya Manusia. Bandung : PT. Remaja Rosda Karya. 2009.

[2] Achmad Nuruddin S, dan Agus Prayitno. Sistem Pendukung Keputusan Promosi Karyawan Dengan Metode Matching Profile Pada Yayasan Pendidikan Nasima Semarang. 2011.

[3] Andi Prastowo. Menguasai Teknikteknik Koleksi Data Penelitian Kualitatif. Jogjakarta: DIVA Press. 2010.
[4] Edi Faizal. Implementasi Metode Profile matching Untuk Penerimaan Usulan Penelitian Internal Dosen STMIK El Rahma. 2014.

[5] Fitriani, N. A. Pengawasan Pimpinan Dalam Meningkatkan Kinerja Pegawai Negri Sipil di Kantor Pelayanan Kekayaan Negara dan Lelang Kota Samarinda. 2013.

[6] Hasibuan, Malayu S.P. Manajemen Sumber Daya Manusia Edisi Revisi. Jakarta : Bumi Aksara. 2011.

[7] I Nyoman Ega Beerawa. Rancang Bangun Sistem Pendukung Keputusan Seleksi Tenaga Kerja dengan Metode Profile Matching. 2012. http://jurnal.stikom.edu/index.php/jsika /article/view/92/87

[8] Iqbal. Sistem Pendukung Keputusan Penentuan Penempatan PTT (Pegawai Tidak Tetap) Pada Kabupaten Bireuen. 2011.

[9] Kusrini. Konsep Dan Aplikasi Sistem Pendukung Keputusan. Yogyakarta : Andi. 2007.

[10] Pardosi, J . Tambunan, MM, dan Syahputri, K. Pengukuran Kinerja dengan menggunakan integrasi $360^{\circ}$ Feed Back \& AHP di PT. S. e-Jurnal Teknik Industri FT USU. 3(2):1-7. 2013. 